\title{
Heat-stress abatement during the dry period: Does cooling improve transition into lactation?
}

\author{
B. C. do Amaral, ${ }^{*}$ E. E. Connor, $†$ S. Tao, ${ }^{*}$ J. Hayen, ${ }^{\star}$ J. Bubolz, ${ }^{*}$ and G. E. Dahl ${ }^{* 1}$ \\ *Department of Animal Sciences, University of Florida, Gainesville 32611 \\ †Bovine Functional Genomics Laboratory, USDA-ARS, Beltsville Agricultural Research Center, Beltsville, MD 20705
}

\begin{abstract}
Environmental factors, especially temperature and light exposure, influence the health and productivity of dairy cows during lactation, possibly via similar physiological mechanisms. For example, heat stress is a critical component of decreased milk yield during summer. However, less is known about the effect of heat stress during the dry period. The objective of this study was to evaluate the effects of heat stress prepartum under a controlled photoperiod on lactation performance and hepatic metabolic gene expression of periparturient multiparous Holstein cows $(\mathrm{n}=16)$. Cows were dried off approximately $46 \mathrm{~d}$ before expected calving date and assigned to treatment randomly after blocking by mature equivalent milk production and parity. Treatments consisted of either heat stress (HT) or cooling (CL) with fans and sprinklers, both under a photoperiod of 14L:10D. Rectal temperature was measured twice daily during the dry period. After calving, cows were housed in a freestall barn with cooling devices, and milk yield was recorded daily up to $210 \mathrm{~d}$ in milk. Blood samples were taken from dry off until $+42 \mathrm{~d}$ relative to calving for metabolites and from -2 until $+2 \mathrm{~d}$ relative to calving for hormone analysis. Daily dry matter intake was measured from -35 to $+42 \mathrm{~d}$ relative to calving. Liver biopsies were collected at dry off, -20 , +2 , and $+20 \mathrm{~d}$ relative to calving for cows on HT (n $=5)$ and CL $(\mathrm{n}=4)$ to measure mRNA expression of suppressors of cytokine signaling-2 (SOCS-2), insulinlike growth factor binding protein-5 (IGFBP-5), a key transcription factor in lipid biosynthesis $(S R E B P-1 c)$, and enzymes of lipid metabolism (FASN, ACACA, and $A C A D V L)$ by real-time quantitative PCR. Heat stress increased rectal temperatures $\left(39.2\right.$ vs. $\left.38.8^{\circ} \mathrm{C}\right)$, plasma prolactin concentrations at -1 (171 vs. $79 \mathrm{ng}$ / $\mathrm{mL}$ ) and $0 \mathrm{~d}$ (210 vs. $115 \mathrm{ng} / \mathrm{mL}$ ) relative to calving, and decreased dry matter intake at 0 and +14 d relative to calving and $3.5 \%$ fat-corrected milk postpartum
\end{abstract}

Received May 1, 2009

Accepted September 4, 2009.

${ }^{1}$ Corresponding author: gdahl@ufl.edu
(26.1 vs. $35.4 \mathrm{~kg} / \mathrm{d}$ ) compared with CL cows. Relative to CL cows, hepatic mRNA expression of SOCS-2 and $I G F B P-5$ was downregulated in HT cows. Expression of $A C A D V L$ was upregulated in CL cows at $\mathrm{d}+2$ but downregulated at $\mathrm{d}+20$ relative to HT cows. Concentrations of $\mathrm{C} 16: 0$ and cis $\mathrm{C} 18: 1$ were greater in the milk and liver of CL cows compared with HT cows, which reflects greater lipid mobilization. These results suggest that heat-stress abatement in the dry period improves subsequent lactation, possibly via suppression of plasma prolactin surge around calving, SOCS-2 expression, and regulation of hepatic lipid metabolism.

Key words: dairy cattle, dry period, heat stress, gene expression

\section{INTRODUCTION}

Environmental factors, especially temperature and photoperiod, influence the health and productivity of dairy cows during lactation, possibly via similar physiological effects. Heat stress during lactation accounts for 10 to $25 \%$ of milk production loss (Collier et al., 2006). Exposure of cows to cooling during the dry period increases milk production relative to animals exposed to heat stress (Avendaño-Reyes et al., 2006) as reported by Collier et al. (1982b), but the mechanisms remain unclear.

Long-day photoperiod during lactation also improves milk yield, whereas short-day photoperiod during the dry period improves health and subsequent lactation performance (Dahl, 2008). The photoperiodic effect observed in dry cows is mediated through prolactin (PRL) signaling (Schams and Reinhardt, 1974; Auchtung et al., 2005; Wall et al., 2005b), which affects mammary cell differentiation and growth (Wall et al., 2005a), immune function (Auchtung et al., 2004), the IGF-axis, and lactation performance (Dahl, 2008). Of interest, high temperatures increase circulating PRL (Collier et al., 1982a, 2008). Thus, PRL might provide a consistent endocrine mechanism to initiate the effects of photoperiod and heat stress on productivity and health of dairy cows.

Furthermore, there is evidence to support a link between PRL signaling and hepatic lipid metabolism 
(Dahl, 2008). Exposure of growing steers to short-day photoperiod for 6 wk reduced hepatic mRNA expression of acetyl-CoA carboxylase $(\boldsymbol{A C A C A})$ and very long chain acyl-CoA dehydrogenase $(\boldsymbol{A} \boldsymbol{C A D V L}$ ) (Connor et al., 2007). Savage et al. (2006) demonstrated that blocking $A C A C A$ increases fat oxidation, inhibits lipogenesis, and reduces the concentration of malonyl-CoA in rat liver. Loor et al. (2005) reported a positive association between $A C A D V L$ mRNA and increased concentrations of circulating NEFA and hepatic triacylglycerol, which are hallmarks of fatty liver in dairy cows. Thus, a reduction in $A C A C A$ and $A C A D V L$ mRNA expression might represent less fat mobilization, which should be desirable in the transition cow.

Because long days increase PRL and increased PRL during the dry period is associated with depressed performance in the next lactation, a similar response might result from heat-stress-induced increases in PRL in dry cows. However, the effect of heat stress under a controlled photoperiod during the dry period has not been investigated. Furthermore, the effect of heat stress during late pregnancy on hepatic lipid metabolism is unknown but might represent a significant factor in subsequent performance. The objectives of the current study were to evaluate the effects of heat stress under a controlled photoperiod during the dry period on hepatic metabolic gene expression and subsequent lactation performance of periparturient dairy cows. The hypothesis was that cooling of dry cows under a controlled photoperiod would enhance subsequent performance relative to heat-stressed cows and that the effects of cooling would be mediated by changes in hepatic metabolic gene expression and suppression of circulating PRL.

\section{MATERIALS AND METHODS}

\section{Animals, Treatments, and Sampling}

The experiment was conducted at the University of Florida Dairy Research Unit in Hague, Florida. All experimental animals were managed according to the guidelines approved by the University of Florida Institute of Food and Agricultural Sciences Animal Research Committee. Multiparous Holstein cows were dried off $46 \mathrm{~d}$ before expected calving according to standard protocol of the University of Florida Dairy Research Unit, which consisted of cessation of milking and intramammary infusion of each quarter with antibiotic (Quartermaster, Pfizer, Kalamazoo, MI). Cows were assigned randomly to treatment after blocking by mature equivalent milk production and parities. Treatments were imposed during the dry period only and included heat stress $(\mathbf{H T} ; \mathrm{n}=9)$ or cooling
$(\mathbf{C L} ; \mathrm{n}=7)$. The cooling system consisted of fans (J\&D Manufacturing, Eau Claire, WI) and sprinklers (Rainbird Manufacturing, Glendale, CA) that turned on automatically whenever the ambient temperature exceeded $21.1^{\circ} \mathrm{C}$. Treatments began at dry off (from August 20 to September 17, 2007) and continued until calving (September 21 to November 3, 2007). Both treatments had a photoperiod of $14 \mathrm{~L}: 10 \mathrm{D}$ provided by metal halide lights at approximately $250 \mathrm{~lx}$ at cow eye level, approximately $3 \mathrm{~m}$ above the stall floor. For both treatments, the lights were on at $0600 \mathrm{~h}$ and off at 2000 h. Rectal temperature was measured twice daily during the entire dry period. Prepartum cows were housed in sand-bedded freestalls and individually fed using Calan gates (American Calan Inc., Northwood, NH). When signs of parturition were detected, the cows were moved to an adjacent sand-bedded pen with shade and water. After calving, all cows were housed together in a sandbedded, freestall barn equipped with fans, sprinklers, and Calan gates. Milk yield was recorded daily up to 210 DIM postpartum. Daily DMI was measured from dry off to +42 d relative to calving. Dry cows were fed TMR once daily at $0930 \mathrm{~h}$, whereas milking cows were fed TMR twice daily at 0900 and $1300 \mathrm{~h}$ to allow 5 to $10 \%$ feed refusals daily. One sample of corn silage was collected weekly and immediately dried for $1 \mathrm{~h}$ using an electric drier (Koster Crop Tester Inc., Strongsville, $\mathrm{OH})$ to calculate the percentage of DM to maintain the formulated forage-to-concentrate ratio in the ration. Cows were milked twice daily at 0900 and $2100 \mathrm{~h}$. Cows were weighed and body condition scored (Edmonson et al., 1989) at $-46,-32,-18,0,+14,+28$, and $+42 \mathrm{~d}$ relative to calving before feeding during the dry period and after the 0900-h milking and before feeding during the lactation period.

\section{Sample Collection}

Milk samples were collected weekly from 2 consecutive milkings, and bronopol-B-14 was used as a preservative. Milk was measured for fat, true protein, and SCC by Southeast Milk Inc. (Belleview, FL) using a Bentley 2000 NIR analyzer (Bentley Instruments, Chaska, MN). Final concentrations of components were calculated after adjustment for milk production during those milkings. Milk without preservative was collected at 2 consecutive milkings at +35 and $+42 \mathrm{~d}$ relative to calving, pooled based on milk yield (final volume of $45 \mathrm{~mL}$ ), and frozen until fatty acid analysis. Blood $(10 \mathrm{~mL})$ was collected at $0700 \mathrm{~h}$ at $-46,-32,-18$, $0,+14,+28$, and $+42 \mathrm{~d}$ relative to expected calving from coccygeal vessels into sodium-heparinized tubes (Vacutainer, Becton Dickinson, Franklin Lakes, NJ) for metabolite analysis. In addition, blood samples were 
Table 1. Ingredient and chemical composition of TMR fed to Holstein cows during the prepartum and postpartum periods

\begin{tabular}{lcc}
\hline Item & Prepartum & Postpartum \\
\hline Ingredient, \% of DM & & \\
Corn silage & 30.0 & 39.5 \\
Bermudagrass hay & 34.7 & - \\
Alfalfa hay & - & 12.5 \\
Ground corn & 12.0 & 17.4 \\
Corn gluten feed & - & 6.6 \\
Citrus pulp & 10.2 & 5.2 \\
Soybean meal & 6.7 & 6.3 \\
Soyplus 1 & & 8.8 \\
Trace mineralized salt ${ }^{2}$ & 0.1 & - \\
Mineral and vitamin premix, prepartum ${ }^{3}$ & 6.3 & - \\
Mineral and vitamin premix, postpartum & \\
Chemical composition & - & 3.7 \\
NE, Mcal/kg of DM & 1.52 & \\
CP, \% of DM & 14.6 & 1.63 \\
NDF, \% of DM & 40.2 & 32.9 \\
ADF, \% of DM & 24.9 & 20.9 \\
Ether extract, \% of DM & 3.4 & 3.9 \\
Ca, \% of DM & 1.80 & 0.75 \\
P, \% of DM & 0.33 & 0.42 \\
Mg, \% of DM & 0.33 & 0.34 \\
K, \% of DM & 1.41 & 1.60 \\
Na, \% of DM & 0.19 & 0.28 \\
S, \% of DM & 0.42 & 0.23 \\
Cl, \% of DM & 0.76 & 0.44 \\
Fe, mg/kg of DM & 328 & 252 \\
Zn, mg/kg of DM & 50 & 65 \\
Cu, mg/kg of DM & 19 & 24 \\
Mn, mg/kg of DM & 40 & 42 \\
Mo, mg/kg of DM & 1.1 & 1.2 \\
\hline I & & \\
\hline
\end{tabular}

${ }^{1}$ West Central Soy, Ralston, IA.

${ }^{2}$ Trace mineralized salt contained minimum concentrations of $40 \% \mathrm{Na}$, $55 \% \mathrm{Cl}, 0.25 \% \mathrm{Mn}, 0.2 \% \mathrm{Fe}, 0.033 \% \mathrm{Cu}, 0.007 \% \mathrm{I}, 0.005 \% \mathrm{Zn}$, and $0.0025 \%$ Co (DM basis).

${ }^{3}$ Mineral and vitamin premix contained $22.8 \% \mathrm{CP}, 22.9 \% \mathrm{Ca}, 0.20 \% \mathrm{P}$, $0.2 \% \mathrm{~K}, 2.8 \% \mathrm{Mg}, 0.7 \% \mathrm{Na}, 2.4 \% \mathrm{~S}, 8 \% \mathrm{Cl}, 147 \mathrm{mg} / \mathrm{kg}$ of $\mathrm{Mn}, 27 \mathrm{mg} /$ $\mathrm{kg}$ of Fe, $112 \mathrm{mg} / \mathrm{kg}$ of $\mathrm{Cu}, 95 \mathrm{mg} / \mathrm{kg}$ of Zn, $7 \mathrm{mg} / \mathrm{kg}$ of Se, $8 \mathrm{mg} / \mathrm{kg}$ of I, $11 \mathrm{mg} / \mathrm{kg}$ of Co, 268,130 IU of vitamin A/kg, 40,000 IU of vitamin $\mathrm{D} / \mathrm{kg}$, and $1,129 \mathrm{IU}$ of vitamin $\mathrm{E} / \mathrm{kg}$ (DM basis).

${ }^{4}$ Mineral and vitamin mix contained $26.4 \% \mathrm{CP}, 10.2 \% \mathrm{Ca}, 0.90 \% \mathrm{P}$ $3.1 \% \mathrm{Mg}, 1.5 \% \mathrm{~S}, 5.1 \% \mathrm{~K}, 8.6 \% \mathrm{Na}, 1,500 \mathrm{mg} / \mathrm{kg}$ of $\mathrm{Zn}, 512 \mathrm{mg} / \mathrm{kg}$ of $\mathrm{Cu}, 339 \mathrm{mg} / \mathrm{kg}$ of Fe, $2,231 \mathrm{mg} / \mathrm{kg}$ of $\mathrm{Mn}, 31 \mathrm{mg} / \mathrm{kg}$ of Co, $26 \mathrm{mg} /$ $\mathrm{kg}$ of I, $7.9 \mathrm{mg} / \mathrm{kg}$ of Se, $147,756 \mathrm{IU}$ of vitamin $\mathrm{A} / \mathrm{kg}$, and $787 \mathrm{IU}$ of vitamin $\mathrm{E} / \mathrm{kg}$ (DM basis).

taken twice daily from -2 until $+2 \mathrm{~d}$ relative to calving for PRL analysis. Samples were immediately placed on ice until being centrifuged at $2,619 \times g$ at $5^{\circ} \mathrm{C}$ for 30 min. Plasma was separated and frozen at $-20^{\circ} \mathrm{C}$ for subsequent analyses. On $-46,-20,+2$, and $+20 \mathrm{~d}$ relative to calving, liver samples (approximately $400 \mathrm{mg}$ ) were collected via biopsy, rinsed with sterile saline, snap frozen in liquid $\mathrm{N}$, and stored at $-80^{\circ} \mathrm{C}$ until analysis for fatty acids and mRNA abundance.

Representative samples of corn silage, bermudagrass hay, alfalfa hay, and concentrate mixes were collected on a weekly basis. Weekly samples were composited on a monthly basis and ground through a 1-mm Wiley mill screen (A. H. Thomas, Philadelphia, PA). Feed samples (corn silage, bermudagrass hay, alfalfa hay, and concentrate mixes) were analyzed for mineral and fat composition, NDF, ADF, and CP (Dairy One, Ithaca, NY; Table 1).

\section{Analytical Procedures}

Plasma concentrations of PRL were determined on samples taken twice daily from -2 until +2 d relative to calving (do Amaral et al., 2009). Plasma NEFA (NEFA-C Kit, Wako Fine Chemical Industries USA Inc., Dallas, TX; as modified by Johnson and Peters, 1993) and BHBA (Autokit 3-HB, Wako Fine Chemical Industries USA Inc.) concentrations were determined on samples from dry off until $+42 \mathrm{~d}$ postpartum. Under a similar schedule, a Technicon Autoanalyzer (Technicon Instruments Corp., Chauncey, NY) was used to determine concentrations of plasma BUN (a modification of Coulombe and Favreau, 1963, and Marsh et al., 1965) and plasma glucose (a modification of Gochman and Schmitz, 1972).

Fat was isolated from milk by centrifugation of thawed milk at $17,800 \times g$ for $30 \mathrm{~min}$ at $8^{\circ} \mathrm{C}$. Approximately $325 \mathrm{mg}$ of manually isolated fat was extracted using a $3: 2$ (vol/vol) hexane/isopropanol solvent mixture $(18 \mathrm{~mL} / \mathrm{g}$ of fat). The extracted fat was converted to methyl esters according to Chouinard et al. (1999) and subsequently analyzed for fatty acids. Fat extraction and the methylation of liver samples were done according to Kramer et al. (1997). Fatty acid methyl esters of milk and liver samples were determined using a Varian CP-3800 gas chromatograph (Varian Inc., Palo Alto, CA) equipped with auto-sampler (Varian CP-8400), flame ionization detector, and a Varian capillary column (CP-Sil 88; $100 \mathrm{~m} \times 0.25 \mathrm{~mm} \times 0.2 \mu \mathrm{m})$. The carrier gas was helium, the split ratio was 10:1, and the injector and detector temperatures were maintained at 230 and $250^{\circ} \mathrm{C}$, respectively. One microliter of sample was injected via the auto-sampler into the column. The oven temperature was initially set at $120^{\circ} \mathrm{C}$ for $1 \mathrm{~min}$, increased by $5^{\circ} \mathrm{C} / \mathrm{min}$ up to $190^{\circ} \mathrm{C}$, held at $190^{\circ} \mathrm{C}$ for 30 min, increased $2^{\circ} \mathrm{C} / \mathrm{min}$ up to $220^{\circ} \mathrm{C}$, and held at $220^{\circ} \mathrm{C}$ for $40 \mathrm{~min}$. The peak was identified and calculated based on the retention time and peak area of known standards.

\section{Total RNA Isolation and Quantitative PCR}

Total RNA was extracted from liver using the recommended method for isolation of RNA from fatty animal tissues (Qiagen Inc., Valencia, CA). Briefly, liver tissues were homogenized in Qiazol reagent (Qiagen Inc.), followed by chloroform extraction and addition of an equal volume of $70 \%$ (vol/vol) ethanol to the aqueous phase. Total RNA was then isolated using the RNeasy 
Table 2. Primer sequences, annealing temperature, and amplicon size of each gene target analyzed in bovine liver by quantitative real-time PCR

\begin{tabular}{|c|c|c|c|c|}
\hline Gene $^{1}$ & Primer & Sequence $\left(5^{\prime} \rightarrow 3^{\prime}\right)$ & Size, bp & Temperature, ${ }^{\circ} \mathrm{C}$ \\
\hline \multirow[t]{2}{*}{$A C A C A$} & Forward & CCTGGTTGCACAAAAGGATT & 176 & 56.8 \\
\hline & Reverse & TTCTCATCCGGTTCAGCTCT & & \\
\hline \multirow[t]{2}{*}{$A C A D V L$} & Forward & CACCATGAAAGGCATCATTG & 160 & 56.8 \\
\hline & Reverse & GTTGGCACTCACCATGTACG & & \\
\hline \multirow[t]{2}{*}{$F A S N$} & Forward & TCATCCCCCTGATGAAGAAG & 361 & 56.8 \\
\hline & Reverse & AACTCCACAGGTGGGAACAG & & \\
\hline \multirow[t]{2}{*}{$I G F B P-5$} & Forward & AAAGAAGCTGACCCAGTCCA & 100 & 60.0 \\
\hline & Reverse & CCCCTGCTCAGATTTCTGTC & & \\
\hline \multirow[t]{2}{*}{ SOCS-2 } & Forward & GGGATGCTTCCСТTCСТAAG & 145 & 60.0 \\
\hline & Reverse & GTGCTGGGACCTTTCACCTA & & \\
\hline \multirow[t]{2}{*}{$S R E B P-1 c$} & Forward & CCGAGGCCAAGTTGAATAAA & 136 & 56.8 \\
\hline & Reverse & TTCAGCGATTTGCTTTTGTG & & \\
\hline
\end{tabular}

${ }^{1} A C A C A=$ acetyl-CoA carboxylase; $A C A D V L=$ very long-chain acyl-CoA dehydrogenase; $F A S N=$ fatty acid synthase; IGFBP-5 = insulin-like growth factor binding protein-5; SOCS-2 = suppressor of cytokine signaling-2; $S R E B P-1 c=$ sterol regulatory element binding protein-1c.

Mini Kit and on-column DNase digestion (Qiagen Inc.). The quality of RNA was determined using the Agilent 2100 Bioanalyzer with RNA 6000 Nano LabChip Kits (Agilent Technologies, Palo Alto, CA), and RNA concentration was determined using a NanoDrop ND-1000 spectrophotometer (NanoDrop Technologies, Rockland, DE). The iScript cDNA Synthesis Kit (Bio-Rad Laboratories, Hercules, CA) was used for first-strand cDNA synthesis using $2 \mu \mathrm{g}$ of total RNA per $80-\mu \mathrm{L}$ reaction volume. A parallel negative control reaction was performed in the absence of reverse transcriptase enzyme. Reaction conditions were $25^{\circ} \mathrm{C}$ for $5 \mathrm{~min}, 42^{\circ} \mathrm{C}$ for 30 min, and $85^{\circ} \mathrm{C}$ for $5 \mathrm{~min}$.

Transcript abundance for each gene was determined by absolute quantitative real-time PCR using the BioRad iCycler or MyiQ Real-Time PCR Detection System (Bio-Rad Laboratories). Reactions were performed in duplicate using $2 \mu \mathrm{L}$ of cDNA, $0.4 \mu \mathrm{mol}$ of each primer, and $12.5 \mu \mathrm{L}$ of iQ SYBR Green Supermix (Bio-Rad Laboratories) in a $25-\mu \mathrm{L}$ reaction volume. Reaction cycling conditions were $95^{\circ} \mathrm{C}$ for 3 min followed by 45 cycles at $94^{\circ} \mathrm{C}$ for $15 \mathrm{~s}$, annealing temperature for 30 $\mathrm{s}$, and $72^{\circ} \mathrm{C}$ for $30 \mathrm{~s}$ with fluorescence measurement during the extension step. Table 2 summarizes primer sequences, annealing temperature, and amplicon size of each gene target. Identity of amplification products was confirmed by direct sequencing of gel-purified PCR-amplification products (QIAquick Gel Extraction Kit, Qiagen Inc.) using a CEQ8000 automated DNA sequencer and DTCS Quickstart Chemistry (Beckman Coulter, Fullerton, CA). Concentrations of amplicons were determined using the NanoDrop ND-1000 Spectrophotometer and used to create calibration curves for each gene. Standards ranging from $10^{2}$ to $10^{7}$ molecules were analyzed in duplicate with each assay. A single negative control reaction was run for each experimental sample, and a single blank reaction using water as tem- plate was included with each standard curve. Quantities of transcripts in each sample were automatically determined by interpolation from the standard curve by the iQ or MyiQ software. Final transcript abundance was expressed as the number of molecules per unit of total RNA used in the reverse transcription reaction.

\section{Statistical Analysis}

Measurements of daily DMI during the pre- and postpartum periods, milk production, and milk composition were reduced to weekly means before statistical analyses were performed. Milk fatty acids, dry period length, and calf BW were analyzed using PROC GLM of SAS (SAS Institute, Cary, NC). Repeated measures data (DMI, milk production, milk fat, milk protein, BW, BCS, plasma PRL, NEFA, BUN, plasma glucose, and liver fatty acids) were analyzed using PROC MIXED procedures of SAS. The model included the fixed effect of treatment, time, and treatment by time interaction and the random effect of cow. Data were tested to determine the structure of best fit, namely $\mathrm{AR}(1), \mathrm{ARH}(1), \mathrm{CS}$, or $\mathrm{CSH}$, as indicated by a lower Schwartz Bayesian information criterion value (Littell et al., 1996). Standard error of the mean is reported.

\section{RESULTS}

\section{Rectal Temperature, Barn Temperature, and Relative Humidity}

As expected, rectal temperature during the afternoon period was greater for HT cows compared with $\mathrm{CL}$ cows $\left(39.2\right.$ vs. $\left.38.8^{\circ} \mathrm{C}, \mathrm{SEM}=0.1^{\circ} \mathrm{C} ; P=0.05\right)$. However, rectal temperature in the morning period was not different between treatments $\left(38.7\right.$ vs. $38.6^{\circ} \mathrm{C}$, SEM $\left.=0.1^{\circ} \mathrm{C} ; P=0.35\right)$. In addition, barn temperature and 
relative humidity during the day did not differ between treatments $(P=0.94$ and $P=0.74$ for barn temperature and relative humidity, respectively; Figure 1).

\section{Dry Period Length and Calf Weight}

Cows exposed to HT tended to have a dry period $7 \mathrm{~d}$ shorter than those exposed to CL (38 vs. $45 \mathrm{~d}$, respectively, $\mathrm{SEM}=3 \mathrm{~d} ; P=0.12$ ). Calf $\mathrm{BW}$ was 13 $\mathrm{kg}$ lighter for calves born from HT cows compared with those born from CL cows (31 vs. $44 \mathrm{~kg}, \mathrm{SEM}=2 \mathrm{~kg}$; $P<0.001)$.

\section{Milk Production, Milk Composition, and DMI}

Cows exposed to CL during the dry period produced on average $7.5 \mathrm{~kg} / \mathrm{d}$ more milk than cows exposed to HT (Table $3 ; P=0.01$ ). Milk production adjusted for components $(3.5 \%$ FCM, $3.5 \%$ fat- and protein-corrected milk, and ECM) across the 30-wk postpartum period (Table 3 and Figure 2) was greater for CL cows compared with HT cows. Cows exposed to CL had greater concentration $(P=0.07)$ and yield $(P=0.01)$ of milk fat compared with HT cows. There was no difference between treatments in the percentage of protein in milk $(P=0.62$; Table 3$)$. However, yield of protein tended to be greater $(P=0.09)$ from CL cows than from HT cows (Table 3$)$. Cows exposed to CL had greater $(P=$ 0.06) feed efficiency during the first $42 \mathrm{~d}$ postpartum compared with HT cows.

Cows exposed to HT during the dry period had similar DMI (as \% of BW; Figure 3) compared with CL

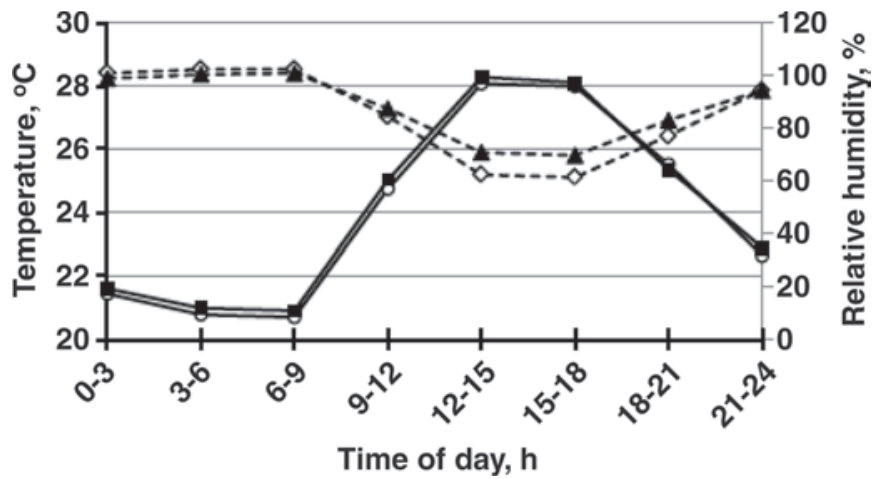

Figure 1. Barn temperature and relative humidity during the dry period. Solid line with solid squares (ם) represents the cooling treatment (CL) barn temperature, and solid line with open circles $(O)$ represents the heat-stress treatment (HT) barn temperature. Dashed line with solid triangles ( $\mathbf{\Delta})$ represents CL barn relative humidity, and dashed line with open diamonds $(\diamond)$ represents HT barn relative humidity. The $x$-axis represents an average of 8 time points during the day (3-h intervals). Temperature and relative humidity in the barn did not differ between treatments $(P=0.94$ and $P=0.74$ for barn temperature and relative humidity, respectively). cows from dry off until -14 d relative to calving. As parturition approached, however, DMI decreased in CL cows (as \% of BW) by approximately $50 \%$ by day of parturition, and CL cows still had less intake by $+14 \mathrm{~d}$ relative to HT cows (Figure $3 ; P=0.03$ ).

\section{Prolactin and Metabolites}

Cows exposed to HT had a greater concentration of PRL in plasma at -1 (171 vs. $79 \mathrm{ng} / \mathrm{mL}, \mathrm{SEM}=28$ $\mathrm{ng} / \mathrm{mL} ; P=0.03$; Figure 4$)$ and $0 \mathrm{~d}(210$ vs. $115 \mathrm{ng} /$ $\mathrm{mL}, \mathrm{SEM}=24 \mathrm{ng} / \mathrm{mL} ; P=0.01$; Figure 4) relative to calving.

Cows exposed to CL had a greater concentration of NEFA in plasma around parturition compared with cows exposed to HT (Figure 5). The concentration of BHBA increased in CL cows at +14 and +28 d postpartum (Figure 5). Plasma concentration of glucose (71 vs. $71 \mathrm{mg} / \mathrm{dL}, \mathrm{SEM}=1 \mathrm{mg} / \mathrm{dL} ; P=0.88)$ and BUN $(11.2$ vs. $11.3 \mathrm{mg} / \mathrm{dL}, \mathrm{SEM}=0.50 \mathrm{mg} / \mathrm{dL} ; P=0.92)$ did not differ between treatments.

\section{Hepatic Gene Expression}

The mRNA expression of sterol regulatory element binding protein-1c ( $\boldsymbol{S R E B P - 1} \boldsymbol{c} ; 96$ vs. $79 \%$ of baseline for HT and CL cows, respectively, SEM $=15 \% ; P=$ 0.56 ), ACACA (97 vs. $92 \%$ of baseline for HT and CL cows, respectively, SEM $=22 \% ; P=0.88$ ), and fatty acid synthase ( $\boldsymbol{F A S N} ; 136$ vs. $97 \%$ of baseline for HT and CL cows, respectively, $\mathrm{SEM}=28 \% ; P=0.33) \mathrm{did}$ not differ between treatments.

The mRNA expression of $A C A D V L$ in liver of CL cows was upregulated at $+2 \mathrm{~d}$ relative to calving compared with cows exposed to HT (treatment by day interaction; $P<0.01$; Table 4). However, at +20 d relative to calving, the mRNA expression of $A C A D V L$ was downregulated for CL cows compared with HT cows. Relative to HT cows, CL cows had upregulated hepatic mRNA expression of suppressor of cytokine signaling-2 (SOCS-2; Table 4) and insulin-like growth factor binding protein-5 (IGFBP-5; Table 4).

\section{Fatty Acid Profiles in Milk and Liver}

Cows exposed to CL had lesser concentrations of C8:0, C10:0, C12:0, C14:0, and C15:0 in milk compared with HT cows (Table $5 ; P \leq 0.05$ ). The fatty acid profile reflected lesser concentrations of de novo fatty acids being synthesized in the mammary gland of CL cows relative to HT cows (Table $5 ; P=0.02$ ).

Cows exposed to CL had a greater concentration of cis-9 C18:1 in milk compared with HT cows (Table 5; $P=0.03)$. Concentrations of monounsaturated fatty 


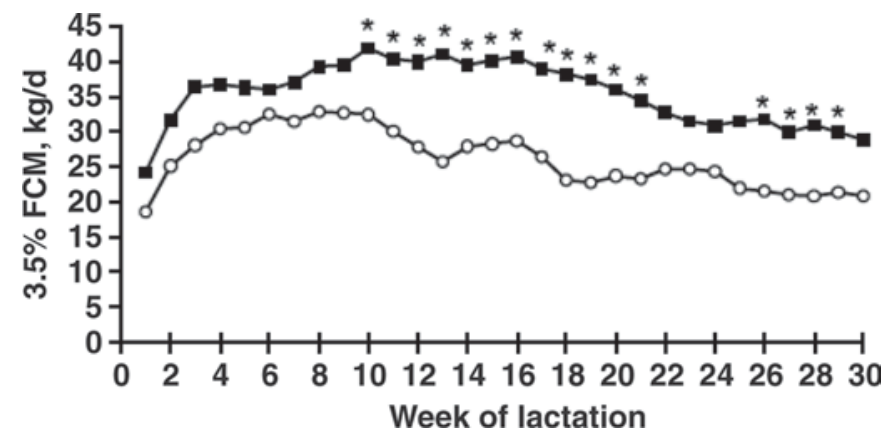

Figure 2. Effect of cooling $(\mathrm{CL} ; \mathrm{n}=7)$ or heat stress $(\mathrm{HT} ; \mathrm{n}=9)$ during a 46-d dry period on the production of milk during the subsequent lactation. Solid squares (ם) represent cows exposed to CL, and open circles $(\bigcirc)$ represent cows under HT. Cows exposed to CL had greater production of milk than cows exposed to HT during the first 30 wk of lactation. ${ }^{*} P<0.05 ; \mathrm{SEM}=2.3 \mathrm{~kg} / \mathrm{d}$. After parturition, cows were housed together in the same barn equipped with fans and sprinklers.

acids in milk fat were greater for CL cows relative to those for HT cows (Table 5; $P=0.03$ ), mainly because of greater mobilization of cis-9 C18:1 from adipose tissue of CL cows (Table 5; $P=0.03$ ). Because of the shift in the monounsaturated fatty acids, polyunsaturated fatty acids were less in milk fat of cows exposed to CL compared with the HT treatment (Table 5; $P=$ 0.01) primarily because of a decrease in cis-9, trans-11 conjugated linoleic acid (0.51 vs. 0.63\%), C18:3 (0.28 vs. $0.33 \%$ ), and $\mathrm{C} 20: 4$ (0.19 vs. $0.23 \%$ ).

Similar to the milk fatty acid profile, the concentration of cis-9 C18:1 was greater $(P<0.01)$ and $\mathrm{C} 16: 0$ tended $(P=0.09$; Table 6$)$ to be greater at $+2 \mathrm{~d}$ relative to calving in hepatic tissue of CL cows compared with HT cows. The concentration of monounsaturated fatty acids in the liver of cows exposed to CL was greater, whereas the concentration of polyunsaturated fatty acids was lesser, at $+2 \mathrm{~d}$ relative to calving compared with HT cows $(P<0.01$; Table 6$)$.

\section{DISCUSSION}

Testing the hypothesis that cooling of dry cows under a controlled photoperiod would improve hepatic metabolism and subsequent lactational performance required confirmation that heat-stress abatement was achieved. As expected, rectal temperatures of HT cows were greater than those of CL cows, which indicates that the cooling system (fans and sprinklers) was effective in reducing animal temperature despite similar barn temperature and relative humidity. Similarly, Avendaño-Reyes et al. (2006) reported that cows cooled with water spray and fans had lower rectal temperature and respiration rate than heat-stressed cows. Lesser BW of the calves from HT cows is additional evidence of heat stress during the dry period, as is the increase in circulating PRL (Collier et al., 1982a; Wolfenson et al., 1988; do Amaral et al., 2009). Therefore, our model was appropriate for the identification of hepatic mechanisms that support the subsequent effects of dry-period cooling on milk yield.

Table 3. Milk yield, 3.5\% FCM yield, 3.5\% FPCM yield, ECM yield, milk components, and feed efficiency for cows exposed to heat stress (HT; $\mathrm{n}=9$ ) or cooling $(\mathrm{CL} ; \mathrm{n}=7$ ) during an expected 46-d dry period

\begin{tabular}{|c|c|c|c|c|}
\hline Variable & $\mathrm{HT}$ & CL & SEM & $P$-value \\
\hline Milk yield, $\mathrm{kg} / \mathrm{d}$ & 26.2 & $33.7^{*}$ & 2.3 & 0.04 \\
\hline $3.5 \% \mathrm{FCM}^{1}{ }^{1} \mathrm{~kg} / \mathrm{d}$ & 26.1 & $35.4^{* *}$ & 2.3 & 0.01 \\
\hline $3.5 \% \mathrm{FPCM}^{2}{ }^{2} \mathrm{~kg} / \mathrm{d}$ & 26.0 & $34.5^{*}$ & 2.3 & 0.02 \\
\hline $\mathrm{ECM},{ }^{3} \mathrm{~kg} / \mathrm{d}$ & 26.3 & $34.9^{*}$ & 2.3 & 0.02 \\
\hline Fat, \% & 3.5 & 3.9 & 0.1 & 0.07 \\
\hline Protein, \% & 3.2 & 3.0 & 0.1 & 0.62 \\
\hline Fat yield, $\mathrm{kg} / \mathrm{d}$ & 0.9 & $1.3^{* *}$ & 0.1 & 0.01 \\
\hline Protein yield, $\mathrm{kg} / \mathrm{d}$ & 0.8 & 1.0 & 0.1 & 0.09 \\
\hline Feed efficiency ${ }^{4}$ & 1.4 & 2.0 & 0.2 & 0.06 \\
\hline $\mathrm{BW},{ }^{5} \mathrm{~kg}$ & 633 & $698^{* *}$ & 16 & 0.01 \\
\hline $\mathrm{BCS}^{5}$ & 3.0 & $3.6^{* *}$ & 0.1 & 0.01 \\
\hline \multicolumn{5}{|l|}{ DMI, $\mathrm{kg} / \mathrm{d}$} \\
\hline Prepartum, d -46 to -1 & 12.0 & $14.1^{* * *}$ & 0.4 & 0.001 \\
\hline Postpartum, d 0 to 42 & 19.3 & 17.7 & 1.3 & 0.36 \\
\hline
\end{tabular}

${ }^{1} 3.5 \% \mathrm{FCM}=(0.4324 \times$ milk yield $)+(16.216 \times$ milk fat yield $)$.

${ }^{2} 3.5 \%$ fat- and protein-corrected milk $(\mathrm{FPCM})=(12.82 \times \mathrm{kg}$ of fat $)+(7.13 \times \mathrm{kg}$ of protein $)+(0.323 \times \mathrm{kg}$ of milk).

${ }^{3} \mathrm{ECM}=(0.327 \times \mathrm{kg}$ of milk $)+(12.95 \times \mathrm{kg}$ of fat $)+(7.20 \times \mathrm{kg}$ of protein $)($ Tyrrell and Reid, 1965).

${ }^{4}$ Feed efficiency $=\mathrm{kg}$ of $3.5 \% \mathrm{FCM} / \mathrm{kg}$ of DMI. Feed efficiency was calculated daily from calving until $+42 \mathrm{~d}$ relative to calving.

${ }^{5} \mathrm{BW}$ and $\mathrm{BCS}$ were measured at $-46,-32,-18$, and 0 d relative to expected calving date.

${ }^{*} P<0.05 ;{ }^{* *} P<0.01 ;{ }^{* * *} P<0.001$. 


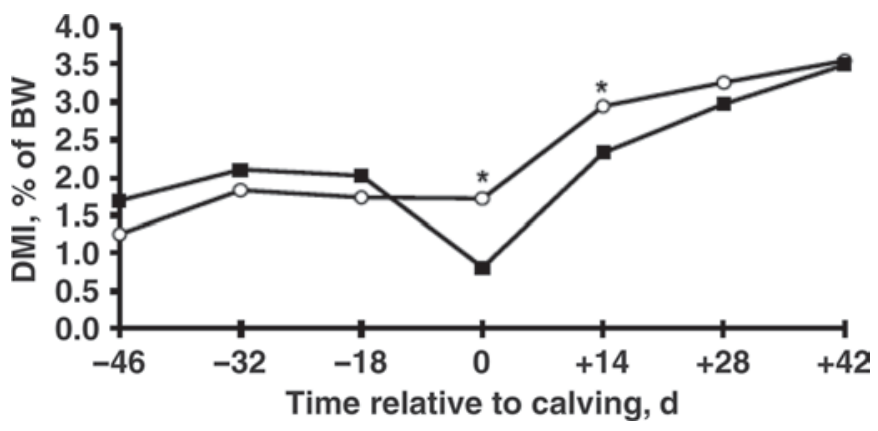

Figure 3. Effect of cooling (CL; $\mathrm{n}=7$ ) or heat stress $(\mathrm{HT} ; \mathrm{n}=9)$ during a 46-d dry period on DMI as a percentage of BW before and after calving. Solid squares ( $)$ represent cows exposed to CL, and open circles $(O)$ represent cows exposed to HT. There was no difference between groups in DMI during the dry period $(P=0.54)$. ${ }^{*}$ During the initial $+14 \mathrm{~d}$ of lactation, cows exposed to CL had lesser DMI (\% of $\mathrm{BW}$ ) relative to those exposed to HT (treatment by week interaction; $P<0.05)$. After parturition, cows were housed together in the same barn equipped with fans and sprinklers.

Results of the current study confirm that exposure of cows to CL during the dry period increases milk production relative to animals exposed to HT, as observed previously (Wolfenson et al., 1988; Avendaño-Reyes et al., 2006; Urdaz et al., 2006). Milk fat concentration and yield were greater for CL cows compared with HT cows. Similarly, Avendaño-Reyes et al. (2006) reported an increase in milk fat yield in the subsequent lactation with cows that were cooled prepartum compared with cows under heat stress. It must be emphasized, however, that there were differences in the duration and intensity of cooling among previous studies and the current experiment. For example, Collier et al. (1982b) provided only shade as a heat-stress abatement, whereas the HT cows in our study were shaded. Urdaz et al. (2006) only cooled cows during the final 3 wk of the dry period, whereas we cooled for the entire dry period. These experimental differences might explain the apparently large milk-yield response in the current study relative to earlier reports.

Collier et al. (1982b) attributed the effects of heat stress during late gestation to reduced placental and maternal hormone production, which in turn reduced mammary gland growth and postpartum function. Although the current study focused on an alternate endocrine mechanism related to PRL signaling, our results do not exclude the possibility that a reduction in placental function might also contribute to the lesser milk yield of HT cows. Indeed, given the aforementioned spectrum of responses to dry-period heat-stress abatement on subsequent yield, it is likely that multiple factors are responsible for the loss of production.

To our knowledge, this is the first experiment to evaluate the effect of heat stress under a controlled photoperiod during the entire dry period on DMI. Not surprisingly, actual DMI was less in HT cows during the entire dry period (Table 3), but adjustment for BW eliminated that difference. However, CL cows had less DMI (as \% of BW) at 0 and $+14 \mathrm{~d}$ postpartum, likely because of a greater BCS of CL relative to HT cows (Table 3). Indeed, Hayirli et al. (2003) reported that obese cows have a greater drop in DMI as percentage of BW from the last 3 wk of gestation until calving compared with normal cows, which corroborates the results in the current experiment.

Similar to other reports (Collier et al., 1982a; Urdaz et al., 2006), NEFA concentrations in plasma during the prepartum period were not affected by heat stress. However, at $0,+14$, and +28 d relative to calving, CL cows had greater concentrations of NEFA compared with HT cows, which is likely because of less DMI at 0 and $+14 \mathrm{~d}$ coupled with greater milk production in the previously cooled cows. Holtenius et al. (2003) reported that the magnitude of increase in NEFA concentration in plasma after parturition was inversely related to the DMI before parturition, which is consistent with our results. It is important to emphasize that the NEFA concentrations around parturition were elevated in CL cows but not to a pathological extent because milk yield clearly did not suffer relative to that of HT cows. Thus, prepartum cooling appears to improve the cow's ability to navigate the metabolic challenges of the transition when compared with heat stress. In addition, PRL is known to be involved in the regulation of fat metabolism in several species (Ling and Billig, 2001) through suppression of lipoprotein lipase in adipose tissue (Zinder et al., 1974). Thus, greater concentrations of PRL in HT cows possibly suppressed lipoprotein lipase activity

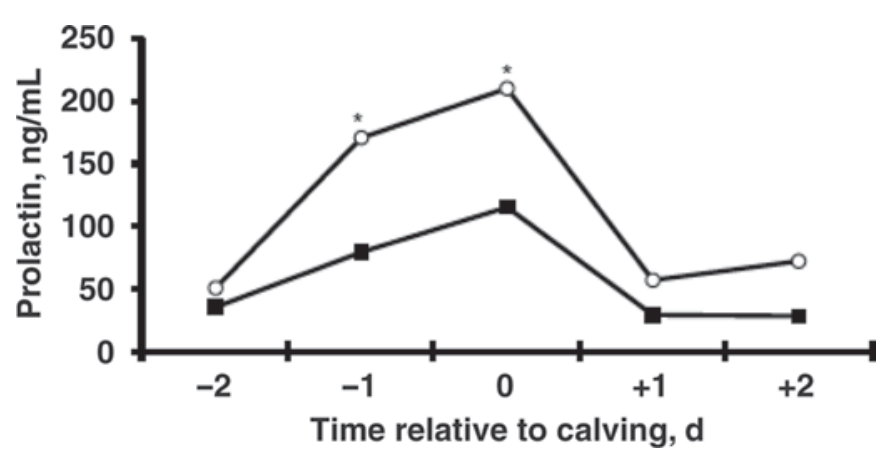

Figure 4. Effect of cooling (CL; $\mathrm{n}=7$ ) or heat stress $(\mathrm{HT} ; \mathrm{n}=9)$ during a 46-d dry period on plasma concentrations of prolactin from -2 until $+2 \mathrm{~d}$ relative to calving. Solid squares ( $)$ represent prolactin concentration of CL cows, and open circles $(O)$ represent prolactin concentrations of HT cows. Cows exposed to HT had a greater concentration of prolactin at $-1 \mathrm{~d}$ (171 vs. $79 \mathrm{ng} / \mathrm{mL}, \mathrm{SEM}=28 \mathrm{ng} / \mathrm{mL}$; $P=0.03)$ and $0 \mathrm{~d}(210$ vs. $115 \mathrm{ng} / \mathrm{mL}, \mathrm{SEM}=24 \mathrm{ng} / \mathrm{mL} ; P=0.01)$ relative to calving. ${ }^{*} P<0.05$. After parturition, cows were housed together in the same barn equipped with fans and sprinklers. 
Table 4. Hepatic mRNA expression of very long-chain acyl-CoA dehydrogenase (ACADVL), suppressor of cytokine signaling-2 (SOCS-2), and insulin-like growth factor binding protein-5 (IGFBP-5) of cows exposed to heat stress $(\mathrm{n}=5)$ or cooling $(\mathrm{n}=4)$ during a targeted $46-\mathrm{d}$ dry period on $-46,-20,+2$, and +20 d relative to calving ${ }^{1}$

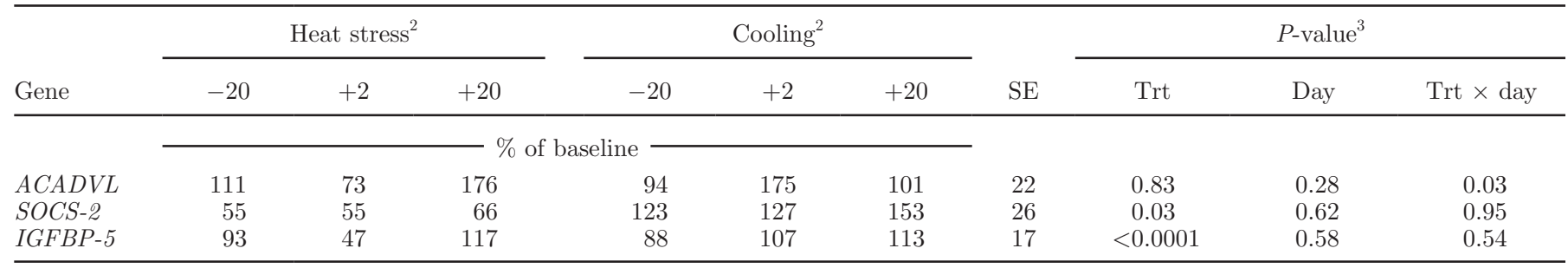

${ }^{1}$ Sample taken at $-46 \mathrm{~d}$ relative to calving was considered to be the baseline.

${ }^{2}$ Biopsies were collected at $-20,+2$, and +20 d relative to calving.

${ }^{3}$ Trt $=$ treatment.

in adipose tissue such that lipid hydrolysis was reduced and, consequently, NEFA decreased.

Following the increase in NEFA concentrations in plasma of CL cows, there was an increase in BHBA concentration in plasma at +14 and +28 d relative to calving. One explanation for this response is that an overload of NEFA in the liver, and subsequent excess of acetyl CoA that could not enter the TCA cycle, caused a shift in the pathway toward ketone body production. But similar to increased NEFA, greater BHBA concentrations did not compromise lactation performance. This suggests that CL cows, relative to HT cows, had a greater capacity to cope with increased lipid mobilization in support of greater milk yield. Douglas et al. (2006) reported that cows given feed ad libitum prepartum had greater BCS during the dry period, a greater drop in DMI around parturition, and increased concentrations of NEFA and BHBA postpartum, similar to the current experiment. This is a metabolic adaptation to support lactation during the transition period (Drackley, 1999).

The enzyme ACADVL is one of the 5 acyl-CoA dehydrogenases that catalyze the initial, rate-limiting step of mitochondrial fatty acid $\beta$-oxidation (McAndrew et al., 2008). The fat mobilized from adipose tissue is oxidized in the liver by ACADVL. Hepatic mRNA expression of $A C A D V L$ was upregulated at $+2 \mathrm{~d}$ relative to calving in CL cows versus HT cows. This is consistent with hepatic metabolic adaptation to accommodate greater lipid mobilization around parturition. However, unexpectedly, the mRNA expression of $A C A D V L$ was downregulated at $+20 \mathrm{~d}$ relative to calving in CL cows compared with HT cows despite greater NEFA concentrations in plasma.

The mechanisms whereby tissue sensitivity to PRL is controlled are not well understood (Tam et al., 2001). Suppressors of cytokine signaling proteins comprise a family of intracellular proteins (Yoshimura et al., 2007) that are stimulated by PRL and act through feedback to inhibit cytokine signaling (Wall et al., 2005b). For example, PRL injections to lactating rats treated with bromocriptine induced SOCS-1, SOCS-2, and SOCS3 mRNA expression in the ovary, but no increase in SOCS-2 was observed in the adrenal gland (Tam et al., 2001). Dairy cows exposed to short-day photoperiod have less PRL concentrations in plasma (Dahl, 2008) and less SOCS-2 mRNA expression in the mammary gland at $-24 \mathrm{~d}$ relative to calving (Wall et al., 2005b). However, in the current study, SOCS-2 was greatly expressed in the liver of CL cows compared with HT cows, possibly because of differences in tissue specificity between the liver and mammary gland. To date, there is only limited information on the effects of heat stress on the mammary-gland gene expression in dairy cows, and it would be relevant to further investigate the expression of PRL signaling genes in the mammary gland of heat-stressed animals.

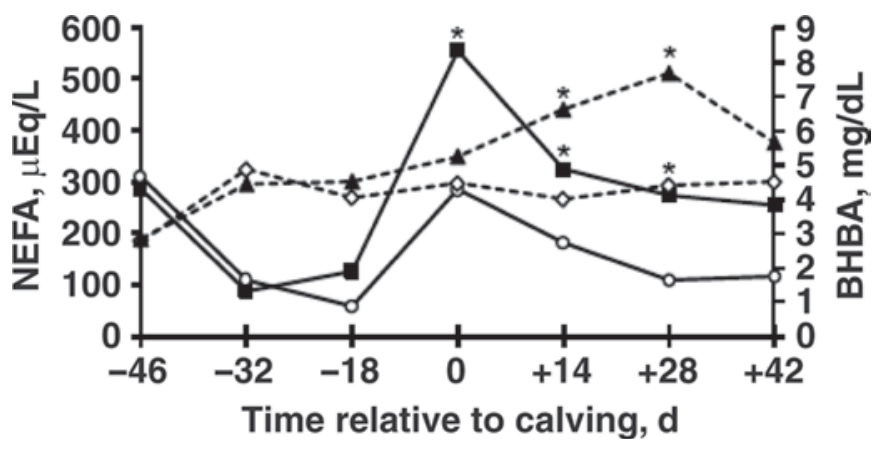

Figure 5. Effect of cooling (CL; $\mathrm{n}=7$ ) or heat stress $(\mathrm{HT} ; \mathrm{n}=9)$ during a 46-d dry period on plasma concentrations of NEFA from dry off until +42 d relative to calving. Solid line with solid squares ( represents NEFA concentration of CL cows, and solid line with open circles $(\bigcirc)$ represents NEFA concentrations of HT cows. Dashed line with solid triangles $(\mathbf{\Lambda})$ represents BHBA concentrations of CL cows, and dashed line with open diamonds $(\diamond)$ represents BHBA concentration of HT cows. Cows exposed to CL had a greater concentration of NEFA at $0,+14$, and $+28 \mathrm{~d}$ relative to calving. Cows exposed to CL had a greater concentration of BHBA at +14 and +28 d relative to calving. ${ }^{*} P<0.05 ;$ SEM $=50 \mu \mathrm{Eq} / \mathrm{L}$ for NEFA and SEM $=1.5 \mathrm{mg} /$ $\mathrm{dL}$ for BHBA. After parturition, cows were housed together in the same barn equipped with fans and sprinklers. 
Table 5. Milk fatty acid profiles of cows exposed to heat stress (HT; $\mathrm{n}=9$ ) or cooling (CL; $\mathrm{n}=7$ ) during a targeted 46-d dry period ${ }^{1}$

\begin{tabular}{|c|c|c|c|c|}
\hline Fatty acid $^{2}$ & HT & $\mathrm{CL}$ & SEM & $P$-value \\
\hline & \multicolumn{4}{|c|}{$-\%$ of identified fatty acid -} \\
\hline C6:0 & 2.49 & 2.26 & 0.12 & 0.21 \\
\hline C8:0 & 1.63 & $1.37^{*}$ & 0.08 & 0.05 \\
\hline C10:0 & 3.83 & $3.00^{* *}$ & 0.21 & 0.01 \\
\hline $\mathrm{C} 12: 0$ & 4.33 & $3.30^{* *}$ & 0.25 & 0.01 \\
\hline $\mathrm{C} 14: 0$ & 13.18 & $10.78^{*}$ & 0.69 & 0.02 \\
\hline C15:0 & 1.19 & $0.85^{* *}$ & 0.07 & $<0.01$ \\
\hline $\mathrm{C} 16: 0$ & 33.50 & 32.16 & 0.90 & 0.30 \\
\hline cis-9 C16:1 & 0.37 & $0.33^{*}$ & 0.01 & 0.04 \\
\hline $\mathrm{C} 17: 0$ & 0.73 & 0.71 & 0.02 & 0.46 \\
\hline C18:0 & 13.06 & 13.95 & 0.53 & 0.25 \\
\hline C18:1 trans family & 1.72 & 1.53 & 0.08 & 0.09 \\
\hline cis-9 C18:1 & 18.96 & $25.20^{*}$ & 1.90 & 0.03 \\
\hline C18:2 n-6 & 3.63 & 3.38 & 0.11 & 0.12 \\
\hline cis-9, trans-11 CLA & 0.63 & $0.51^{* *}$ & 0.03 & $<0.01$ \\
\hline trans-10, cis-12 CLA & $\mathrm{ND}^{3}$ & ND & ND & - \\
\hline C20:0 & 0.15 & 0.14 & 0.01 & 0.59 \\
\hline C18:3 n-3 & 0.33 & $0.28^{* *}$ & 0.01 & 0.01 \\
\hline $\mathrm{C} 20: 4 \mathrm{n}-6$ & 0.23 & $0.19^{*}$ & 0.01 & 0.04 \\
\hline de novo fatty acids ${ }^{4}$ & 43.40 & $37.65^{*}$ & 1.69 & 0.02 \\
\hline MUFA $^{5}$ & 21.06 & $27.06^{*}$ & 1.87 & 0.03 \\
\hline PUFA $^{6}$ & 4.83 & $4.36^{* *}$ & 0.12 & 0.01 \\
\hline PUFA/MUFA & 0.29 & 0.17 & 0.05 & 0.13 \\
\hline \multicolumn{5}{|c|}{$\begin{array}{l}{ }^{1} \text { Values represent means of daily morning and evening milk samples during wk } 5 \text { and } 6 \text { postpartum }(\mathrm{n}=14) \\
\text { pooled based on milk yield. }\end{array}$} \\
\hline \multicolumn{5}{|c|}{${ }^{2} \mathrm{CLA}=$ conjugated linoleic acid. } \\
\hline \multicolumn{5}{|l|}{${ }^{3} \mathrm{ND}=$ not detected. } \\
\hline \multicolumn{5}{|c|}{${ }^{4}$ de novo fatty acids $=$ C6:0 + C8:0 + C10:0 + C12:0 + C14:0 + C15:0 + (C16:0/2). } \\
\hline \multicolumn{5}{|c|}{${ }^{5}$ Monounsaturated fatty acids $(\mathrm{MUFA})=$ cis-9 C16:1 + C18:1 trans family + cis-9 C18:1. } \\
\hline \multicolumn{5}{|c|}{$\begin{array}{l}{ }^{6} \text { Polyunsaturated fatty acids }(\mathrm{PUFA})=\mathrm{C} 18: 2+\mathrm{C} 18: 3+\text { cis- } 9 \text {, trans-11 CLA }+ \text { trans- } 10 \text {, cis-12 CLA } \\
\text { C20:4. }\end{array}$} \\
\hline
\end{tabular}

Another explanation for the increase in SOCS-2 mRNA expression in the liver of CL cows could be linked to estrogens. Collier et al. (1982b) reported that dry cows under shade had greater concentrations of plasma estrone sulfate and numerically greater concentrations of estradiol-17 $\left(\mathbf{E}_{2}\right)$ compared with heat-stressed cows. Concentrations of $\mathrm{E}_{2}$ increase at parturition, and the hormone upregulates SOCS-2 (Winkelman et al., 2008). Leong et al. (2004) reported that short-term treatment of mice with $\mathrm{E}_{2}$ did not upregulate hepatic SOCS-2 mRNA. However, mice receiving $\mathrm{E}_{2}$ injections for 3 wk had greater SOCS-2 mRNA than controls, which indicates that SOCS-2 upregulation requires long-term elevations of $\mathrm{E}_{2}$. In the current experiment, CL cows had upregulated expression of SOCS-2 mRNA in the liver compared with HT cows, possibly because of a greater concentration of $\mathrm{E}_{2}$ in plasma for the entire dry period that the animals were heat stressed.

It appears that IGFBP-5 has a dual role in tissue turnover by reducing the availability of the survival factor IGF-I, as well as increasing extracellular matrix degradation, thereby coordinating apoptosis and tis- sue remodeling (Nørgaard et al., 2008). Cows exposed to CL had upregulated hepatic mRNA expression of IGFBP-5 compared with HT cows. During involution of the mammary gland in rodents, mammary epithelial cells increase production of IGFBP-5, and PRL prevents this increase in IGFBP-5 (Allan et al., 2004). Because the liver undergoes dramatic metabolic changes in preparation for lactation, greater circulating PRL in HT cows might have limited the normal increase in $I G$ FBP-5 and, thus, hepatic remodeling, setting the stage for a reduction in the capacity for lipid metabolism relative to that of CL cows.

Milk contains fatty acids derived from de novo synthesis by the mammary gland (C4:0 to C14:0 plus a portion of $\mathrm{C} 16: 0)$ and from mammary uptake of preformed fatty acids (i.e., a portion of C16:0 and all longer chain fatty acids; Zheng et al., 2005). In the current study, the greater lipid mobilization of CL cows probably influenced de novo fatty synthesis in the mammary gland and the uptake of preformed fatty acids. Relative to HT cows, the most common fatty acids in adipose tissue (C16:0 and cis $\mathrm{C} 18: 1)$ were in greater 
Table 6. Hepatic fatty acid profiles of cows exposed to heat stress $(n=9)$ or cooling $(n=7)$ during a targeted 46-d dry period on -46 , -20 , +2 , and +20 d relative to calving

\begin{tabular}{|c|c|c|c|c|c|c|c|c|c|c|c|c|}
\hline Fatty acid ${ }^{1}$ & \multicolumn{4}{|c|}{ Heat stress ${ }^{2}$} & \multicolumn{4}{|c|}{ Cooling $^{2}$} & $\mathrm{SE}$ & \multicolumn{3}{|c|}{$P$-value ${ }^{3}$} \\
\hline C14:0 & 0.31 & 0.40 & 0.44 & 0.38 & 0.38 & 0.28 & 1.80 & 1.35 & 0.41 & 0.24 & 0.45 & 0.34 \\
\hline C16:0 & 7.40 & 7.05 & 15.96 & 13.36 & 8.23 & 9.83 & 26.75 & 18.23 & 2.49 & 0.06 & $<0.0001$ & 0.09 \\
\hline cis-9 C16:1 & 0.13 & 0.33 & 0.08 & 0.14 & 0.05 & 0.10 & 0.23 & 0.18 & 0.11 & 0.79 & 0.66 & 0.14 \\
\hline cis-9 C18:1 & 10.02 & 13.24 & 15.76 & 13.58 & 9.00 & 10.55 & 26.75 & 18.45 & 2.56 & 0.30 & $<0.001$ & 0.01 \\
\hline $\mathrm{C} 18: 2 \mathrm{n}-6$ & 15.06 & 12.46 & 13.14 & 15.78 & 13.95 & 12.13 & 9.95 & 13.45 & 0.83 & 0.10 & $<0.001$ & 0.17 \\
\hline cis- 9 , trans-11 CLA & 0.07 & 0.12 & 0.22 & 0.16 & 0.15 & 0.14 & 0.22 & 0.17 & 0.05 & 0.63 & 0.21 & 0.68 \\
\hline trans-10, cis-12 CLA & 0.03 & 0.00 & 0.02 & 0.01 & 0.01 & 0.01 & 0.00 & 0.00 & 0.01 & 0.45 & 0.43 & 0.42 \\
\hline C18:3 n-3 & 0.46 & 0.84 & 0.80 & 0.63 & 0.45 & 0.94 & 0.88 & 0.60 & 0.08 & 0.66 & $<0.0001$ & 0.76 \\
\hline C20:0 & 0.05 & 0.07 & 0.09 & 0.09 & 0.06 & 0.07 & 0.06 & 0.05 & 0.07 & 0.58 & 0.67 & 0.62 \\
\hline $\mathrm{C} 22: 6 \mathrm{n}-3$ & 0.31 & 0.27 & 0.34 & 0.28 & 0.30 & 0.33 & 0.21 & 0.31 & 0.12 & 0.94 & 0.98 & 0.60 \\
\hline MUFA $^{4}$ & 10.86 & 14.62 & 16.58 & 14.38 & 9.75 & 11.45 & 27.82 & 19.38 & 2.60 & 0.30 & $<0.001$ & 0.01 \\
\hline $\mathrm{PUFA}^{5}$ & 45.79 & 42.50 & 37.35 & 40.40 & 45.23 & 42.96 & 23.10 & 33.40 & 3.00 & 0.12 & $<0.001$ & 0.03 \\
\hline PUFA/MUFA & 4.67 & 3.14 & 2.39 & 3.50 & 4.78 & 3.77 & 0.87 & 2.27 & 0.63 & 0.47 & $<0.001$ & 0.12 \\
\hline n- $6 / n-3$ ratio $^{6}$ & 1.84 & 1.94 & 2.25 & 2.50 & 1.64 & 1.60 & 2.77 & 2.69 & 0.28 & 0.88 & 0.01 & 0.23 \\
\hline
\end{tabular}

${ }^{1} \mathrm{CLA}=$ conjugated linoleic acid.

${ }^{2}$ Biopsies were collected at $-45,-20,+2$, and +20 d relative to calving.

${ }^{3}$ Trt $=$ treatment

${ }^{4}$ Monounsaturated fatty acids (MUFA) $=$ cis-9 C16:1 + C18:1 trans family + cis-9 C18:1.

${ }^{5}$ Polyunsaturated fatty acids $(\mathrm{PUFA})=\mathrm{C} 18: 2+\mathrm{C} 18: 3+$ cis- 9, trans-11 CLA + trans- 10, cis- 12 CLA + C20:3 + C20:4 + C20:5 + C22:5 + C22:6.

${ }^{6} \mathrm{n}-6 / \mathrm{n}-3$ ratio $=(\mathrm{C} 18: 2+$ cis-9, trans-11 CLA + trans-10, cis-12 CLA + C20:4)/(C18:3 + C20:3 + C20:5 + C22:5 + C22:6).

concentration in the milk of CL cows, whereas the fatty acids synthesized de novo were reduced. Rukkwamsuk et al. (2000) reported that C16:0 and cis C18:1 were greater in plasma of cows that were overfed during the prepartum period and that mobilized more body reserves, indicating that these preformed fatty acids will be taken up by the mammary gland as reported in the current study.

Proportions of the various fatty acids in the liver of dairy cows are influenced primarily by hepatic uptake of fatty acids from the circulation, and to a lesser extent by their metabolism (i.e., de novo synthesis, desaturation, and chain elongation of fatty acids within the liver; Sato et al., 2004). The capacity for synthesis (Emery et al., 1992), as well as desaturation (Bell, 1981; St. John et al., 1991), of fatty acids is limited in the ruminant liver. In addition, hepatic lipid composition in the early postpartum period can be altered by prepartum diets or by the extensive mobilization of body fat around parturition, when energy balance is mostly negative (Drackley et al., 2001). The fatty acids that are most common in adipose tissue (C16:0 and cis $\mathrm{C} 18: 1)$ were greater in the liver of CL cows compared with HT cows (Table 5), which reflects greater lipid mobilization. Similarly, Rukkwamsuk et al. (2000) reported that cows overfed during the dry period had a greater concentration of cis C18:1 and numerically greater concentration of $\mathrm{C} 16: 0$ at $0.5 \mathrm{wk}$ postpartum compared with limit-fed cows, which is also a reflection of greater NEFA concentrations postpartum.

In summary, heat-stress abatement during the entire dry period improved subsequent lactation performance, and this was associated with a suppression of PRL concentrations in plasma and changes in hepatic metabolic gene expression that are likely mediated through PRL signaling pathways. Compared with the dry period, the upregulation of $S O C S$ - 2 and $I G F B P-5$ might contribute to the enhancement of the hepatic metabolic capacity of dairy cows to support the energetic challenge of early lactation. In addition, hepatic upregulation of $A C A D V L$ indicates an improvement in hepatic lipid metabolism to cope with fat mobilization and support greater milk 
production. Thus, heat-stress abatement during the entire dry period is a promising management tool to improve the transition into lactation.

\section{ACKNOWLEDGMENTS}

We thank the staff at the Dairy Research Unit, Institute of Food and Agricultural Sciences, University of Florida, especially Eric Diepersloot, for care of the cows and assistance in obtaining the data collected in this study.

\section{REFERENCES}

Allan, G. J., J. Beattie, and D. J. Flint. 2004. The role of IGFBP-5 in mammary gland development and involution. Domest. Anim. Endocrinol. 27:257-266.

Auchtung, T. L., A. G. Rius, P. E. Kendall, T. B. McFadden, and G. E. Dahl. 2005. Effects of photoperiod during the dry period on prolactin, prolactin receptor, and milk production of dairy cows. J. Dairy Sci. 88:121-127.

Auchtung, T. L., J. L. Salak-Johnson, D. E. Morin, C. C. Mallard, and G. E. Dahl. 2004. Effects of photoperiod during the dry period on cellular immune function of dairy cows. J. Dairy Sci. 87:36833689.

Avendaño-Reyes, L., F. D. Alvarez-Valenzuela, A. Correa-Calderón, J. S. Saucedo-Quintero, P. H. Robinson, and J. G. Fadel. 2006. Effect of cooling Holstein cows during the dry period on postpartum performance under heat stress conditions. Livest. Sci. 281:25352547.

Bell, A. W. 1981. Lipid metabolism in liver and selected tissues and in the whole body of ruminant animals. Page 363 in Lipid Metabolism in Ruminant Animals. W. W. Christie, ed. Pergamon Press, Oxford, UK.

Chouinard, P. Y., L. Corneau, A. Sæbø, and D. E. Bauman. 1999 Milk yield and composition during abomasal infusion of conjugated linoleic acid. J. Dairy Sci. 82:2737-2745.

Collier, R. J., D. K. Beede, W. W. Thatcher, L. A. Israel, and C. J. Wilcox. 1982a. Influences of environment and its modification on dairy animal health and production. J. Dairy Sci. 65:2213-2227.

Collier, R. J., J. L. Collier, R. P. Rhoads, and L. H. Baumgard. 2008. Invited review: Genes involved in bovine heat stress response. J. Dairy Sci. 91:445-454.

Collier, R. J., G. E. Dahl, and M. J. VanBaale. 2006. Major advances associated with environmental effects on dairy cattle. J. Dairy Sci. 89:1244-1253.

Collier, R. J., S. G. Doelger, H. H. Head, W. W. Thatcher, and C. J. Wilcox. 1982b. Effects of heat stress during pregnancy on maternal hormone concentrations, calf birth weight and postpartum milk yield of Holstein cows. J. Anim. Sci. 54:309-319.

Connor, E. E., E. D. Thomas, and G. E. Dahl. 2007. Photoperiod alters metabolic gene expression in bovine liver potentially through suppressors of cytokine signaling. J. Anim. Sci. 85(Suppl. 1):208. (Abstr.)

Coulombe, J. J., and L. Favreau. 1963. A new simple method for colorimetric determination of urea. Clin. Chem. 9:102-108.

Dahl, G. E. 2008. Effects of short day photoperiod on prolactin signaling in dry cows: A common mechanism among tissues and environments. J. Anim. Sci. 86:10-14.

do Amaral, B. C., E. E. Connor, S. Tao, J. Hayen, J. Bulbolz, and G. E. Dahl. 2009. Heat stress abatement during the dry period influences prolactin signaling in lymphocytes. Domest. Anim. Endocrinol. doi:10.1016/j.domaniend.2009.07.005

Douglas, G. N., T. R. Overton, H. G. Bateman II, H. M. Dann, and J. K. Drackley. 2006. Prepartal plane of nutrition, regardless of dietary energy source, affects periparturient metabolism and dry matter intake in Holstein cows. J. Dairy Sci. 89:2141-2157.

Drackley, J. K. 1999. Biology of dairy cows during the transition period: The final frontier? J. Dairy Sci. 82:2259-2273.
Drackley, J. K., T. R. Overton, and G. N. Douglas. 2001. Adaptations of glucose and long-chain fatty acid metabolism in liver of dairy cows during the periparturient period. J. Dairy Sci. 84(E. Suppl.):E100-E112.

Edmonson, A. J., I. J. Lean, L. D. Weaver, T. Farver, and G. Webster. 1989. A body condition score chart for Holstein dairy cows. J. Dairy Sci. 72:68-78.

Emery, R. S., J. S. Liesman, and T. H. Herdt. 1992. Metabolism of long chain fatty acids by ruminant liver. J. Nutr. 122(Suppl. 3):832-837.

Gochman, N., and J. M. Schmitz. 1972. Application of a new peroxide indicator reaction to the specific automated determination of glucose with glucose oxidase. Clin. Chem. 18:943-950.

Hayirli, A., R. R. Grummer, E. V. Nordheim, and P. M. Crump. 2003. Models for predicting dry matter intake of Holteins during the prefresh transition period. J. Dairy Sci. 86:1771-1779.

Holtenius, K., S. Agenas, C. Delavaud, and Y. Chilliard. 2003. Effects of feeding intensity during the dry period. 2. Metabolic and hormonal responses. J. Dairy Sci. 86:883-891.

Johnson, M. M., and J. P. Peters. 1993. Technical note: An improved method to quantify non-esterified fatty acids in bovine plasma. J Anim. Sci. 71:753-756.

Kramer, J. K. G., V. Feliner, M. E. R. Dugan, F. D. Sauer, M. M. Mossoba, and M. P. Yarawecz. 1997. Evaluating acid and base catalysts in the methylation of milk and rumen fatty acids with special emphasis on conjugated dienes and total trans fatty acids. Lipids 32:1219-1228.

Leong, G. M., S. Moverare, J. Brce, N. Doyle, K. Sjögren, K. DahlmanWright, J. Gustafsson, K. K. Y. Ho, C. Ohlsson, and K. Leung. 2004. Estrogen up-regulates hepatic expression of suppressors of cytokine signaling-2 and -3 in vivo and in vitro. Endocrinology 145:5525-5531.

Ling, C., and H. Billig. 2001. PRL receptor-mediated effects in female mouse adipocytes: PRL induces suppressors of cytokine signaling expression and suppresses insulin-induced leptin production in adipocytes in vitro. Endocrinology 142:4880-4890.

Littell, R. C., G. A. Milliken, W. W. Stroup, and R. D. Wolfinger. 1996. SAS for Mixed Models. SAS Institute Inc., Cary, NC.

Loor, J. J., H. M. Dann, R. E. Everts, R. Oliveira, C. A. Green, N. A. Guretzky, S. L. Rodriguez-Zas, H. A. Lewin, and J. K Drackley. 2005. Temporal gene expression profiling of liver from periparturient dairy cows reveals complex adaptive mechanisms in hepatic function. Physiol. Genomics 23:217-226.

Marsh, W. H., B. Fingerhut, and H. Miller. 1965. Automated and manual direct methods for the determination of blood urea. J. Clin. Chem. 6:624-627.

McAndrew, R. P., Y. Wang, A. W. Mohsen, M. He, J. Vockley, and J. J. Kim. 2008. Structural basis for substrate fatty acyl chain specificity: Crystal structure of human very-long chain acyl-CoA dehydrogenase. J. Biol. Chem. 283:9435-9443.

Nørgaard, J. V., P. K. Theil, M. T. Sorensen, and K. Sejrsen. 2008. Cellular mechanisms in regulating mammary cell turnover during lactation and dry period in dairy cows. J. Dairy Sci. 91:23192327.

Rukkwamsuk, T., M. J. H. Geelen, T. A. M. Kruuip, and T. Wensing. 2000. Interrelation of fatty acid composition in adipose tissue, serum, and liver of dairy cows during the development of fatty liver postpartum. J. Dairy Sci. 83:52-59.

Sato, H., T. Mohamed, A. Goto, S. Oikawa, and T. Kurosawa. 2004 Fatty acid profiles in relation to triglyceride level in the liver of dairy cows. J. Vet. Med. Sci. 66:85-87.

Savage, D. B., C. S. Choi, V. T. Samuel, Z. X. Liu, D. Zhang, A. Wang, X. M. Zhang, G. W. Cline, X. X. Yu, J. G. Geisler, S. Bhanot, B. P. Monia, and G. I. Shulman. 2006. Reversal of diet-induced hepatic steatosis and hepatic insulin resistance by antisense oligonucleotide inhibitors of acetyl-CoA carboxylases 1 and 2. J. Clin. Invest. 116:817-824.

Schams, D., and V. Reinhardt. 1974. Influence of the season on plasma prolactin levels in cattle from birth to maturity. Horm. Res. $5: 217-226$ 
St. John, L. C., D. K. Lunt, and S. B. Smith. 1991. Fatty acid elongation and desaturation enzyme activities of bovine liver and subcutaneous adipose tissue microsomes. J. Anim. Sci. 69:10641073.

Tam, S. P., P. Lau, J. Djiane, D. J. Hilton, and M. J. Waters. 2001. Tissue-specific induction of SOCS gene expression by PRL. Endocrinology 142:5015-5026.

Tyrrell, H. F., and J. T. Reid. 1965. Prediction of the energy value of cow's milk. J. Dairy Sci. 48:1215-1223.

Urdaz, J. H., M. W. Overton, D. A. Moore, and J. E. P. Santos. 2006. Technical note: Effects of adding shade and fans to a feedbunk sprinkler system for preparturient cows on health and performance. J. Dairy Sci. 89:2000-2006.

Wall, E. H., T. L. Auchtung, G. E. Dahl, S. E. Ellis, and T. B. McFadden. 2005a. Exposure to short day photoperiod during the dry period enhances mammary growth in dairy cows. J. Dairy Sci. 88:1994-2003.

Wall, E. H., T. L. Auchtung-Montgomery, G. E. Dahl, and T. B. McFadden. 2005b. Short communication: Short-day photoperiod during the dry period decreases expression of suppressors of cytoline signaling in mammary gland of dairy cows. J. Dairy Sci. 88:3145-3148.

Winkelman, L. A., M. C. Lucy, T. H. Elsasser, J. L. Pate, and C. K. Reynolds. 2008. Short communication: Suppressor of cytokine signaling-2 mRNA increases after parturition in the liver of dairy cows. J. Dairy Sci. 91:1080-1086.

Wolfenson, D., I. Flamembaum, and A. Berman. 1988. Dry period heat stress relief effects on prepartum progesterone, calf birth weight, and milk production. J. Dairy Sci. 71:809-818.

Yoshimura, A., T. Naka, and M. Kubo. 2007. SOCS proteins, cytokine signaling and immune regulation. Nat. Rev. Immunol. 7:454465.

Zheng, H. C., J. X. Liu, J. H. Yao, Q. Yuan, H. W. Ye, J. A. Ye, and Y. M. Wu. 2005. Effects of dietary sources of vegetable oils on performance of high-yielding lactating cows and conjugated linoleic acids in milk. J. Dairy Sci. 88:2037-2042.

Zinder, O., M. Hamosh, T. R. Fleck, and R. O. Scow. 1974. Effect of prolactin on lipoprotein lipase in mammary glands and adipose tissue of rats. Am. J. Physiol. 226:742-748. 